\title{
Book Review: The Politics of Genocide: The Holocaust in Hungary Vol. I-II. Third Revised and Updated Edition
}

Arpad von Klimo

The Catholic University of America

Follow this and additional works at: https://digitalcommons.usf.edu/gsp

\section{Recommended Citation}

von Klimo, Arpad (2017) "Book Review: The Politics of Genocide: The Holocaust in Hungary Vol. I-II. Third Revised and Updated Edition," Genocide Studies and Prevention: An International Journal: Vol. 11: Iss. 2: 114-115.

DOI:

http://doi.org/10.5038/1911-9933.11.2.1488

Available at: https://digitalcommons.usf.edu/gsp/vol11/iss2/13

This Book Review is brought to you for free and open access by the Open Access Journals at Digital Commons @ University of South Florida. It has been accepted for inclusion in Genocide Studies and Prevention: An International Journal by an authorized editor of Digital Commons @ University of South Florida. For more information, please contact digitalcommons@usf.edu. 


\author{
Arpad von Klimo \\ The Catholic University of America \\ Washington, D.C., USA
}

The Politics of Genocide: The Holocaust in Hungary, Vol. I-II. Third Revised and Updated Edition

Randolph L. Braham

New York, Columbia University Press, 2016

1,825 Pages; Price: \$65.00 Hardcover

Reviewed by Arpad von Klimo

The Catholic University of America, Washington, D.C.

When Randolph Braham's The Politics of Genocide: The Holocaust in Hungary was first published in 1981 it set standards for the research of the 1944 mass murder of the Jews from Hungary. Since then, the book has seen seventy-two editions in four languages (English, Hebrew, Hungarian, and Romanian) and is now held by more than 1,200 libraries worldwide. Because there were only a few studies on the topic published before 1981, mostly in Hungarian, The Politics of Genocide was the first comprehensive, scholarly study of the Holocaust in Hungary.

The two volumes are based on numerous documents from Hungarian, German, and other archives and a growing scholarship in Hungary, the United States, Germany, and other countries. Braham had collected these materials over many years (he published various bibliographies and primary source collections) to tell the story of a very unique part of the Shoah, at times called "the Holocaust after the Holocaust" because it happened after millions of Jews had already been murdered in the extermination campaigns in Eastern Europe between 1941 and the end of 1943 while in Hungary about 800,000 Jews, many of them refugees from other countries, were still alive. In March 1943, Hitler decided to invade Hungary and finish the "final solution." Within a few weeks between late spring and early summer of 1944, about 450,000 Jews from the Hungarian countryside outside Budapest were transported to Auschwitz where most of them were killed. On July 6, 1944, when most Jews outside the capital had already been murdered, Hungary's head of state, Admiral Horthy, gave the order to halt the deportations yielding to international pressure from the West and the Vatican. In October, Horthy was replaced by the fanatic Arrow Cross Party leader Szalasi, who established a reign of terror during which tens of thousands more were killed until the Red Army conquered Budapest in early 1945.

In the new, third edition of The Politics of Genocide, Braham draws on a growing number of meticulous local studies on the deportations of Spring 1944 based on Hungarian archives and mostly published only in Hungarian. His new edition is also based on his monumental threevolume edited Geographical Encyclopedia of the Holocaust in Hungary ${ }^{1}$ which highlighted the role of the Hungarian state officials, administrators, police, and civilians. The Politics of Genocide is narrating and documenting the history of the Holocaust in Hungary in thirty-three chapters, presented in two volumes. Six appendices provide documents on the Labor Service System, the Anti-Jewish laws and decrees, a list of Hungarian and Foreign Jewish authors whose works were banned, a chronology and a list of the deportation trains with numbers of deportees. Compared to the First Edition (1,265 pages, the Second Edition of 1994 had 1,486 pages), this Third edition is almost 600 pages longer. The two volumes tell the story of Jewish Hungarians from the end of World War I which began an era of antisemitic and extreme right-wing activism in Hungary (chapters 1 - 10) until the year 1944, when Hitler decided to occupy Hungary and enforce the "final solution" in the last country of German-dominated Europe where still almost 900,000 Jews had survived the first phase of the Holocaust between 1941 and 1943. The next twenty chapters (11 31) describe the various institutions in Hungary involved in the deportations, attitudes of different

${ }^{1}$ Randolf Braham, ed., The Geographical Encyclopedia of the Holocaust in Hungary (Evanston: Northwestern University Press, 2013). 
actors and organizations in Hungary and abroad, and the execution of the plans of Hungarian and German experts and officials who made it possible that more than 500,000 people were killed within weeks. In the last two chapters (32 and 33), Braham analyzes the periods since the end of the war, including the post-Communist Era since 1989 which began with an intensification of Holocaust remembrance in Hungary and ended, according to the author, with the "fiasco" of the anniversary in 2014 when Braham returned his Hungarian state decorations in protest against the government of Viktor Orban.

Braham provides answers to many of the questions still debated today. He documents in detail the sometimes enthusiastic, murderous efficiency of Hungarian right wing groups, but also of the army, police, railway administration, and gendarmerie during the deportations and the robbery of the victims. Adolf Eichmann and his small group of experts of mass murder had only initiated and observed the execution which was mostly done by Hungarian authorities. Braham is very critical of the behavior of the Jewish Council of Budapest which did not do enough to warn the Jewish population of Hungary. According to his interpretation the Jewish Council contributed to the smooth operation by "lulling the Jewish masses." ${ }^{2}$ However, he concedes that "the Councils were trapped into outright though unwilling collaboration." 3 The complexity of the situation and the difficulty for many Jews to understand that they were denied their Hungarian identity will have to be studied more thoroughly. Braham developed his critical assessment of the Jewish Council while he was teaching at the New School of Social Research in the early 1960s where Hannah Arendt also had a position. It would be interesting to know more about whether they exchanged their views at the time. Braham quotes Arendt but he also provides counter-arguments. ${ }^{4}$ However, he is still critical of the fact that the Jewish leaders did not take the mortal danger seriously before the German invasion of Hungary in March 1944.

The first edition of 1981 appeared in the United States in a time when Holocaust research in Hungary was still restricted by the Communist regime. Only in 1988, a sign of the decline and ongoing dissolution of the party dictatorship, a shortened Hungarian version of The Politics of Genocide could be published. Since then, there have been numerous local and national studies of the Holocaust in Hungary often based on new archival materials from Hungary, the Ukraine, and other places. This made the second, expanded and up-dated English edition of 1994 necessary.

Randolph Braham, who had survived the Holocaust as member of a Hungarian forced labor battalion on the Eastern Front while most members of his family were murdered, has been studying the Holocaust for more than half a century now. He had emigrated to the United States in 1948 published his first two books on the Hungarian Holocaust in 1961 and 1962. These early studies, an extensive bibliography and a collection of documents, Eichmann and the destruction of Hungarian Jewry, were related to the Eichmann trial in Jerusalem. Since then, Braham has produced a number of new studies, narratives, source collections, and extensive bibliographies. The two volumes of the third edition The Politics of Genocide are an indispensable reference for all scholars, students, and others who are interested in the Hungarian Holocaust and the on-going research of this topic.

\footnotetext{
${ }^{2}$ Ibid., $519-5222$

${ }^{3}$ Ibid., 502

${ }^{4}$ Ibid., 978, 1055, 1293
} 